\title{
MENGUNGKAP SISI LAIN BIAYA DALAM UPACARA \\ PELEBON PURI AGUNG UBUD
}

\author{
Oleh: \\ Cokorda Gde Bayu Putra ${ }^{1}$ \\ Anak Agung Ketut Agus Suardika ${ }^{2}$ \\ 1),2)Universitas Hindu Indonesia, email:cokdebayu88@gmail.com
}

\begin{abstract}
This article explains the other meaning of costs in the Traditional Ceremony that took place in the Ubud Village. The purpose of this article is actually to uncover the other side of the cost of the "Pelebon Ceremony" in the Puri Agung Ubud Family. The costs incurred for the implementation of the Pelebon Ceremony are very expensive because it uses many symbols, such as: Bade, Lebu, Tragtag, Banten, pigs and supported by thousands of Ubud people. This article includes qualitative research written using a phenomenological approach through interviews with several important informants. This article succeeded in identifying three other meanings of the costs incurred in the Pelebon Ceremony in Puri Agung Ubud, namely: the concept of Rna (debt), the identity of social strata and family gathering event.
\end{abstract}

\section{Keyword: Cost, Traditional Ceremony, Pelebon, Phenomenological}

\section{PENDAHULUAN}

Pendapatan dan Biaya dalam penyajian laporan keuangan didasarkan pada konsep matching (penandingan). Patton dan Littleton (1940:71) mengungkapkan bahwa masalah utama dalam menandingkan pendapatan dan biaya adalah mencari dasar penandingan yang paling tepat antara pendapatan dengan biaya yang berhubungan langsung dengan pendapatan tersebut. Hasil penelitian yang dilakukan oleh Hanggana (2002) mengungkapkan bahwa terdapat metode akuntansi yang memenuhi konsep macthing namun terdapat pula metode akuntansi yang tidak memenuhi konsep matching. Penandingan antara pendapatan dan biaya telah banyak ditemukan dalam pelaksanaan entitas bisnis berorientasi profit. Namun, konsep penandingan serupa tidak banyak dilakukan pada perspektif budaya.

Pelaporan sebuah organisasi bisnis tentunya tidaklah sama dengan organisasi non profit atau dikenal dengan istilah nirlaba. Biaya yang timbul dalam oranisasi nirlaba tidak memiliki keterkaitan dengan penerimaan (pendapatan) yang akan diperolehnya, hal tersebut dikarenakan 
tujuan organisasi nirlaba bukan untuk memperoleh keuntungan dari aktifitasnya, namun bertujuan untuk mengoptimalkan sumberdaya yang dimiliki dan keberlanjutan pemberian jasa kepada masyarakat (IAI, 2007 dalam Tumirin dan Abdurahim, 2015). Artikel ini mencoba membedah perspektif budaya dalam konsep matching utamanya dalam mengungkap makna biaya dalam tradisi upacara adat Pelebon yang dilaksanakan oleh Keluarga Puri Agung Ubud.

Pelebon atau dikenal dengan istilah "Ngaben" merupakan salah satu bagian dari upacara Agama Hindu di Bali. Upacara Agama Hindu di Bali tercermin pada pelaksanaan Panca Yadnya. Panca Yadnya merupakan lima pengorbanan suci yang dilaksanakan oleh Umat Hindu secara tulus iklhas. Panca Yadnya terdiri dari Dewa Yadnya, Manusa Yadnya, Pitra Yadnya, Rsi Yadnya dan Bhuta Yadnya. Kelima Upacara Yadnya yang dilaksanakan oleh Umat Hindu tersebut tentunya memerlukan pengorbanan biaya yang tidak sedikit.

Upacara Pelebon sebagai bagian dari pitra yadnya dilandasi oleh pitra rna (hutang jasa kepada leluhur). Kepercayaan akan hal tersebut memotivasi umat Hindu untuk menyelenggarakan upacara Pelebon dengan sangat meriah. Namun, di lain sisi terdapat pula sebagian umat Hindu yang melaksanakan upacara dengan sangat sederhana dan hikmat. Karena motivasi yang berlebih terkadang terdapat pula Umat yang melaksanakan upacara tanpa memikirkan resiko yang akan dihadapinya dengan meminjam uang kepada pihak ketiga, padahal sesungguhnya hal itu tidak diwajibkan dan bertentangan dengan konsep ketulusiklhasan.

Biaya yang dikeluarkan dalam kegiatan Upacara Pelebon sebagai bagian dari Upacara Pitra Yadnya yang diselenggarakan oleh keluarga Puri Agung Ubud tidaklah memiliki pengaruh atau keterkaitan dengan perolehan pendapatan, walauapun pengeluaran untuk upacara tersebut memerlukan pengeluaran yang sangat tinggi. Terdapat beberapa dasar pertimbangan yang melatarbelakangi pelaksanaan Upacara Pelebon yang dilaksanakan oleh keluarga Puri Agung Ubud dijadikan sebagai objek penelitian, yaitu: Pertama, pelaksanaan upacara Pelebon tersebut memerlukan biaya yang sangat besar dan membutuhkan sumber daya manusia yang sangat banyak. Biaya yang dikeluarkan untuk menunjang pelaksanaan upacara tersebut berdampak material bagi ekonomi keluarga Puri Agung Ubud, padahal biaya yang dikeluarkan tersebut tidak berdampak signifikan terhadap penerimaan Puri Agung Ubud. Kedua, sebagai bagian pelaksanaan kegiatan adat dan agama, tradisi Pelebon tetap terjaga dan terlaksana hingga saat ini jika terdapat Keluarga Puri Agung Ubud yang meninggal dunia. Ketiga, Upacara Pelebon Puri Agung Ubud ini sangat terkenal sampai ke dunia mancanegara, 
sehingga makna lain biaya dapat menginspirasi dunia internasional untuk penelitian-penelitian berikutnya.

Artikel ini bertujuan untuk mengungkap makna lain dari biaya yang tidak selalu dapat ditandingkan (matching) dengan pendapatan untuk memperoleh keuntungan atau Laba seperti layaknya akuntansi modern bagi organisasi profit oriented. Artikel serupa pernah dilakukan oleh Tumirin dan Abdurahim (2015) yang meneliti tentang Makna Biaya Dalam Upacara Rambu Solo yang dilaksanakan di Kabupaten Toraja Utara Propinsi Sulawesi Selatan. Namun, penelitian terhadap pelaksanaan Pelebon yang dilaksanakan oleh Puri Agung Ubud menarik untuk ditulis karena menggunakan hewan korban dan sumber daya manusia pendukung yang sangat banyak, yaitu masyarakat dari 6 Banjar Adat di Ubud, sehingga pengorbanan biaya banyak dikeluarkan untuk mensukseskan jalannya upacara tersebut.

\section{METODE}

Lokasi penelitian dalam artikel ini adalah di Puri Agung Ubud yang terletak di Desa Pekraman Ubud, Kecamatan Ubud, Kabupaten Gianyar, Provinsi Bali. Pelebon yang dijadikan objek amatan dalam artikel ini adalah Pelebon terhadap mendiang Almarhum Anak Agun Niang Agung (Istri Raja Ubud terakhir-Ida Tjokorda Gde Agung Sukawati). Pelebon tersebut dilaksanakan pada tanggal 2 Maret 2018. Artikel ini menggunakan pendekatan fenomenologi dalam menjelaskan pertanyaan-pertanyaan penulis. Fenomenologi digunakan untuk mengungkap realita esensi subjek atau ideation yang menjelaskan suatu objek yang tampak dalam kesadaran bersatu dengan objek itu sendiri untuk dijadikan makna dalam ilmu pengetahuan. Kuswarno (2009) menjelaskan bahwa kesadaran itu merupakan realitas yang sebenarnya. Lebih lanjut Kuswarno (2009) jua menjelaskan bahwa Fenomenalogi epistimologi mengeluarkan makna dari sesuatu yang material.

Fenomenologi berasal dari asal kata phainomai yang dalam Bahasa Yunani Berarti "menampak". Fenomena didasarkan pada fakta kedalam pembahasan manusia. Fenomena merupakan kesadaran dan disajikan dalam kesadaran, bukan tampak secara kasat mata saja. Fenomenologi menggambarkan pengalaman manusia yang terkait dengan objek (Kuswarno, 2009). Fenomena dan logika Husserl mengantarkan teori Kesengajaan sebagai jantung Fenomenologi. Kesengajaan dan tekanan semantik sebuah makna ideal terpusat pada logika. 
Artikel ini menggunakan data kualitatif. Sejalan dengan penelitian yang dilakukan oleh Tumirin dan Abdurahim (2015), artikel ini juga menggunakan teknik analis data yang disarankan oleh Creswell (2013) dengan susunan sebagai berikut:

1. Mendeskripsikan pengalaman pribadi;

2. Membuat daftar pertanyaan;

3. Mengambil pernyataan penting untuk diambil "makna-nya";

4. Membuat deskrisi tekstual atau apa yang dialami;Membuat deskripsi struktural atau bagaimana pengalaman terjadi;

5. Menulis esensi pengalaman.

Data diperoleh dengan teknik pengumpulan wawancara. Wawancara dilakukan kepada beberapa infoman yang terdiri dari:

a. Informan yang dianggap memiliki pengetahuan terhadap hakekat pelaksanaan upacara Pelebon (Bapak Tjokorda Raka Kerthyasa yang juga sebagai Bendesa Pekraman Ubud). Bendesa merupakan jabatan tertinggi pada sebuah wilayah Desa Adat di Bali.

b. Informan yang dianggap bertanggung jawab atas seluruh pengelolaan sumber daya manusia dan pengelolaan keuangan selama Upacara Pelebon berlangsung (Bapak Tjokorda Gde Raka Sukawati).

c. Informan yang dianggap mengetahui seluruh pengeluaran Babi dan bahan makanan sarana paebatan selama Upacara Pelebon berlangsung (Bapak Cokorda Alit Dharmayudha).

\section{PEMBAHASAN}

\section{Konsep Matching}

Dalam perspektif entitas bisnis, Mulawarman (2008) menjelaskan bahwa konsep matching memiliki keterkaitan yang erat dengan upaya menandingkan antara pendapatan dengan biaya. Segala bentuk pengeluaran dikategorikan sebagai biaya apabila memiliki keterkaitan dengan upaya untuk menghasilkan pendapatan dan biaya tersebut harus diakui pada saat periode perolehan pendapatan dihasilkan oleh sebuah entitas (Ratunuman, 2013; Tyas dan Fachriyah, 2009). Dengan kata lain biaya dipandang sebagai sebuah nilai tukar atau pengorbanan sumber daya yang dilakukan sebuah entitas untuk mendapatkan manfaat di masa yang akan datang. Lebih lanjut Anis Chariri dan Imam Ghozali (2001 : 282) menjelaskan juga 
bahwa pengertian dari konsep perbandingan (matching) yang dimaksudkan adalah untuk mencari dasar hubungan yang tepat dan rasional antara pendapatan dan biaya.

\section{Beberapa Definisi Biaya.}

Hansen et al (2013:47) mendefinisikan biaya sebagai kas atau nilai setara kas yang dikorbankan untuk mendapatkan barang atau jasa yang diharapkan dapat memberi manfaat saat ini atau dimasa yang akan datang bagi organisasi. Pendapat lain dikemukakan oleh Carter et al (2004:29) yang menerangkan biaya sebagai suatu nilai tukar prasyarat atau pengorbanan yang dilakukan guna memperoleh manfaat. Sedangkan biaya menurut Bustami et al (2009:7) adalah pengorbanan sumber ekonomis yang diukur dalam satuan uang yang telah terjadi atau kemungkinan akan terjadi untuk mencapai tujuan tertentu.

\section{Beberapa Definisi Pendapatan}

Pendapatan menurut PSAK no 23 adalah arus masuk bruto dari manfaat ekonomi yang timbul dari aktivitas normal perusahaan selama satu periode bila arus masuk itu mengakibatkan kenaikan akuitas, yang tidak berasal dari kontribusi peranan modal. Menurut Kieso et al (2011 :955), mendefinisikan pendapatan sebagai arus masuk bruto dari manfaat ekonomi yang timbul dari aktivitas normal entitas selama suatu periode, jika arus masuk tersebut mengakibatkan kenaikan ekuitas yang tidak berasal dari kontribusi penanaman modal.

\section{Matching Dalam Perspektif Budaya}

Penandingan pendapatan dan biaya pada perspektif budaya memunculkan makna yang berbeda, karena kepentingan pengelola dan pemilik usaha dalam entitas bisnis berbeda dengan kepentingan pengelola pada lembaga sosial. Operasional bisnis dalam hakekat mencari keuntungan (profit) tidak ditemukan pada organisasi sosial. Para donatur dan pengelola organisasi sosial memilki dasar cara pandang tersendiri memaknai pendapatan dan biaya. Biaya-biaya yang dikeluarkan dalam pelaksanaan kegiatan sosial tidak dipandang sebagai usaha untuk memperoleh pendapatan di kemudian hari. Pandangan tersebut merupakan sebuah kebenaran yang terjadi dalam realita kehidupan masyarakat. Penelitian yang dilakukan oleh Tumirin dan Abdurahim (2015) mengungkapkan bahwa dalam menilai konsep matching melalui bingkai budaya tersirat bahwa pengorbanan biaya dalam pelaksanaan kegiatan ritual upacara tidak memiliki keterkaitan dengan upaya mendapatkan pendapatan sebagaimana konsep matching yang digunakan dalam akuntansi modern. 


\section{Biaya Dalam Pelaksanaan Upacara Pelebon Puri Agung Ubud}

Sebagai Agama Praktis, pelaksanaan Upacara Pelebon tentu bagian dari pelaksanaan ritual keagamaan yang disimbolkan menggunakan simbol-simbol sebagai perlambang kebesaran Ida Sang Hyang Widhi Wasa / Tuhan Yang Maha Esa seperti yang diungkapkan oleh Bapak Tjokorda Raka Kerthyasa sebagai berikut:

“... Upacara Pelebon dilaksanakan sebagai bentuk implementasi terhadap konsep Panca Sradha yang dipecayai masyarakat Bali khususnya keluarga Puri Agung Ubud. Panca Sradha merupakan lima dasar kepecayaan orang Bali yang terdiri dari Percaya akan Brahman, Atman, Karmaphala, Punarbawa, dan Moksa. Lima kepercayaan ini diturunkan dalam pelaksanaan Prawerti Marga atau dikenal dengan Agama Praktik yang menggunakan beberapa simbol-simbol sebagai jembatan mencapai tujuan hidup beragama. Simbol-Simbol yang dimaksud dan digunakan dalam Upacara Pelebon terdiri dari Banten (Upakara)semacam sesajen dan peralatan-peralatan pelengkap lainnya seperti: Bade-tempat mengusung jenazah, dan Lembu-tempat pembakaran jenazah...."

Tatanan Sosial Masyarakat dalam konsep Wangsa di Bali tentu merupakan bagian sejarah dan masih bertahan sampai saat ini di Bali walaupun dalam implementasinya berbeda-beda di setiap daerah di Bali sesuai dengan Desa, Kala, Patra. Desa berarti Tempat, Kala berarti waktu dan Patra menunjukkan situasi dan kondisi. Tatatan Strata Sosial yang diwarisi oleh para leluhur tersebut tercermin dari besarnya tingkatan Upacara yang dilaksanakan secara turun temurun. Keluarga Puri Agung Ubud sebagai bagian Ksatria Wangsa (Bangsawan keturunan Dalem Waturenggong) di Bali sampai saat ini masih menjalankan tradisi pelaksanaan Pelebon dengan menggunakan beberapa simbol-simbol pendukung. Besarnya tingkatan Upacara Pelebon menjukkan tingkatan status sosial masyarakat seperti diungkapkan oleh Bapak Tjokorda Raka Kerthyasa sebagai berikut:

“...Bahwa Upacara Ngaben atau Pelebon di Bali secara filosofi merupakan bagian dari konsep Rna (hutang) yang wajib dibayar oleh sang Anak kepada Orang Tuanya sesuai dengan beberapa tingkatan, yaitu: Nista, Madya, dan Utama. Tingkatan Nista, Madya dan Utama yang dilaksanakan dalam Upacara tersebut harus dilandasi kemampuan, kejujuran dan ketulusiklhasan...”

Puri Agung Ubud menggelar Upacara Pelebon mendiang Almarhum Anak Agung Niang Agung dengan tingkatan Utama dengan menggunakan sarana Banten (Upakara) yang banyak dan Sarana Petulangan Utama (Bade dan Lembu). Sarana Banten dikerjakan langsung 
oleh masyarakat Ubud bersama sama dengan keluarga Puri. Pasokan material sumber daya alam yang digunakan dalam membuat Banten dan sarana lainnya dipersiapkan oleh pihak Puri Agung Ubud dengan melaksanakan pembelian ke supplier dan dengan menerima sumbangan dari para masyarakat yang merasa berhutang atau memiliki sejarah historis dengan Puri Ubud di masa lalu. Lebih lanjut Bapak Tjokorda Gde Raka Sukawati menuturkan:

“....Memang dahulu ketika sumber daya masih banyak, budaya pertanian belum luntur dan hasil bumi masih melimpah, maka segala bentuk sarana penunjang belum memperlihatkan kelangkaan. Dahulu semua bahan janur, bambu, lontar, kelapa dll masih gampang didapat baik itu donasi dari masyarakat maupun hasil pertanian dan perkebunan yang dimiliki oleh Puri. Saat ini ditengah kompleksitas dan mobilitas masyarakat yang kian padat dan sumber daya yang kian langka, maka hampir seluruh sarana pendukung Banten dan sarana petulangan Bade dan Lembu didapatkan dengan cara membeli. Kurang lebih biaya bahan baku yang dibeli kisaran diangka 300-400 juta untuk satu acara Pelebon Agung....'

Hubungan harmonis dan semangat gotong royong antara Keluarga Puri Agung Ubud dan masyarakat Ubud telah terjalin sejak jaman dahulu sampai dengan saat ini. Simbol-simbol yang digunakan dalam pelaksanaan Upacara Pelebon Keluarga Puri Agung Ubud tersebut dipersiapkan bersama antara keluarga Puri Agung Ubud dengan masyarakat Ubud selama kurun waktu 1,5 bulan terhitung semenjak Almarhum meninggal dunia pada tanggal 14 Januari 2018. Sumber Daya Manusia (SDM) yang berasal dari unsur-unsur keluarga besar Puri dan masyarakat Ubud tidak dinilai dengan nilai nominal uang dan tidak bisa dinyatakan sebagai biaya tenaga kerja langsung atau biaya gaji dan kesejahteraan dalam konsep biaya pada perspektif bisnis, seperti yang diungkapkan oleh Bapak Tjokorda Gde Raka Sukawati yang kebetulan sebagai arsitek dan pemimpin proyek pelaksana Upacara Pelebon.

“.....Pekerjaan Yadnya berbeda dengan Pekerjaan Bisnis. Yadnya yang disimbolkan dalam bentuk pelaksanaan Upacara suci adalah murni masalah keiklhasan dan pekerjaan Bisnis adalah murni dalam tujuan profit. Keseluruhan Sumber daya manusia yang terlibat dalam pelaksanaan Pelebon tersebut terdiri dari unsur-unsur Keluarga Puri dan Masyarakat Ubud yang terdiri dari:

1. Desa Pekraman Ubud (Banjar Ubud Kaja, Banjar Ubud Tengah, Banjar Ubud Kelod, Banjar Sambahan)

2. Desa Pekraman Bentuyung Sakti (Banjar Bentuyung dan Banjar Sakti)

3. Banjar Taman Kelod 
Pengorbanan waktu, tenaga dan keahlian yang dimiliki masing-masing unsur pelaksana tersebut tidak bisa dinilai dengan nilai uang, seperti membayarkan sejumlah uang pada ribuan orang yang membantu membuat peralatan dan menggotong bade \& lembu almarhum. Keluarga Puri percaya bahwa hubungan historis antara masyarakat dan keluarga Puri sebagai bentuk penghormatan pada warisan leluhur di masa lalu yang wajib dijaga dan tidak bisa dinilai dengan sejumlah nominal....."

Dalam hal tidak dikeluarkannya nominal besaran uang dalam membiayai sumber daya manusia yang terlibat bukan berarti tidak ada biaya-biaya yang dikeluarkan oleh Keluarga Puri Agung Ubud. Dalam menunjang kelancaran pelaksanaan kegiatan Upacara dan menjaga hubungan yang harmonis, setiap harinya keluarga Puri Agung Ubud menyediakan logistik makanan dan minuman yang dimasak setiap harinya untuk keluarga dan masyarakat Ubud yang hadir. Selama 1,5 bulan pihak Puri menyediakan satap pagi, siang dan malam bagi para keluarga, masyarakat dan para pelayat yang hadir ke Puri Agung Ubud. Responden tidak menyebut berapa pasti besaran nominal yang dikeluarkan untuk itu. Namun di sadari bahwa besaran uang logistik bahan makan yang dikeluarkan sebagai bentuk penghormatan dan keiklhasan kepada mendiang Almarhum serta sebagai bentuk penghormatan pada nilai-nilai toleransi dan keharmonisan pihak Puri dan Masyarakat umum. Seperti yang diungkapkan informan Bapak Tjokorda Gde Raka Sukawati sebagai berikut:

'... bisa dibayangkan kebutuhan logistik selama 30-40 hari kita sediakan bagi para pelayat dan masyarakat yang membantu mempersiapkan Upacara Pelebon dari Santap Pagi, Siang dan Malam... Kami tidak mempermasalahkan besaran biaya yang timbul, namun meyakini bahwa bentuk keiklhasan akan memberikan almarhum jalan yang baik kedepannya dan menjaga hubungan yang harmonis antara Keluarga Puri Agung Ubud dengan Tuhan, Alam, dan Masyarakat Ubud itu sendiri..."

Hubungan yang harmonis dan budaya gotong royong juga tercermin dari proses pengangkatan Bade dan Lembu yang melibatkan ribuan orang masyarakat Ubud menuju Kuburan tempat jenazah Almarhum dikremasi. Dalam melibatkan banyak masyarakat, Pihak Puri Agung Ubud tidak melakukan transaksional nilai uang upah kepada setiap orang yang terlibat. Pendekatan budaya yang digunakan adalah dengan melaksanakan tradisi yang telah terjalin secara turun temurun melalui Paebatan atau Mebat Banjar Adat. Seluruh masyarakat Banjar Adat yang akan menggotong Bade dan Lembu Almarhum akan berkumpul di Balai Banjar masing-masing satu hari menjelang puncak acara untuk bersama sama memotong Babi 
yang dipersembahkan oleh pihak Puri kepada masyarakat Ubud sebagai bentuk ucapan terima kasih dan simbol pasuka-duka dam konsep masyarakat Hukum Adat yang berkembang di Bali.

Banyaknya babi yang digunakan untuk dipotong dalam paebatan jumlahnya variatif berbeda untuk setiap banjar seperti yang dijelaskan oleh informan Bapak Cokorda Alit Dharmayudha sebagi berikut:

“.......Jika dirata-ratakan satu banjar terdiri dari 300 orang krama dengan bagian satu orang mendapatkan jatah jumlah katik 5 atau lima tusuk, akan menghabiskan $1 \mathrm{~kg}$ babi untuk satu tanding krama. Maka, jumlah babi yang dibutuhkan untuk satu banjar adalah rata-rata sebanyak $300 \mathrm{~kg}$ atau dinominalkan sebanyak 18-20 juta per banjar sudah termasuk bahan paebatan makanan lainnya. Jadi keseluruhan bahan termasuk babi yang digunakan untuk 6 Banjar Adat menghabiskan nominal kurang lebih seratus dua puluh juta sampai dua ratus juta selama acara Pelebon..."

Besarnya biaya yang timbul sejalan dengan ritual Upacara Rambu Solo di Tana Toraja yang pernah diteliti oleh Tumirin dan Abdurahim (2015) yang menyatakan bahwa pengorbanan biaya korban (kerbau dan babi) yang digunakan dapat dipandang sebagai pemborosan namun ternyata tidak dianggap berat. Ini terbukti juga pada Pelebon Puri Agung Ubud yang tetap lestari berjalan hingga saat ini.

Ajang Silahturahmi antara Keluarga Puri Agung Ubud dengan Keluarga Puri/Keraton lainnya se-Nusantara, Pemerintahan dan Khalayak Umum tercermin pada Acara Puncak Pelebon Puri Agung Ubud. Sebagai bagian dari Pawongan (hubungan harmonis antara sesama manusia) dalam konsep Tri Hita Karana, Keluarga Puri Agung Ubud senantiasa menjalin tali persaudaraan tatkala ada sebuah prosesi upacara adat yang dilangsungkan pihak Puri Agung Ubud seperti dijelaskan oleh Bapak Tjokorda Gde Raka Sukawati sebagai berikut:

“....Silahturahmi bisa dijadikan sebagai diplomasi budaya untuk saling bertukar pikiran dan mengenal kebudayaan masing-masing. Selain itu, sebagai wujud implementasi pelaksanaan Tri Hita Karana dalam konsep pawongan. ...."

\section{KESIMPULAN}

Biaya yang dibutuhkan untuk pelaksanaan Upacara Pelebon Puri Agung Ubud memang sangat tinggi bahkan terkesan sebagai sebuah pemborosan jika dilihat dari sisi ekonomi. Namun keluarga Puri Agung Ubud mempunyai pandangan tersendiri dalam memberikan makna lain dari biaya untuk pelaksanaan Upacara Pelebon yaitu: pertama, keiklhasan dalam 
memberikan yang terbaik bagi mendiang Almarhum yang dalam konsep masyarakat Bali dikenal dengan konsep Rna atau membayar hutang kepada orang tua dan leluhur. Konsep Rna inilah yang secara persepsi tidak bisa dinilai dengan nominal untuk mendapatkan besaran pendapatan secara langsung layaknya entitas bisnis. Kedua, menunjukkan tatanan status soisal masyarakat yang berkembang di Desa Pekraman Ubud. Keluarga Puri Agung Ubud termasuk dalam strata Ksatria Wangsa atau diistilah sebagai keluarga bangsawan yang tentu dibuktikan dengan Upacara yang besar (utama). Ketiga, seluruh pengeluaran biaya-biaya yang digunakan selama Upacara berlangsung dari awal sampai selesai dianggap sebagai implementasi pelaksanaan konsep Tri Hita Karana (Parhyangan, Pawongan, dan Palemahan). Pawongan sebagai bentuk hubungan harmonis antara keluarga Puri Agung Ubud dengan keluarga besar lainnya dan masyarakat Ubud diwujudkan dalam bentuk semangat gotong royong. Besarnya biaya timbul dalam proses gotong royong dianggap sebagai wujud mempertahankan tali silahturahmi yang sejak lama telah diwarisi dan menjadi roh bagi kelangsungan hidup masyarakat Ubud itu sendiri.

\section{KETERBATASAN}

Artikel ini terbatas pada satu Upacara Pelebon yang dijadikan objek, yaitu Pelebon Anak Agung Niang Agung. Di Bali terdapat banyak Upacara Pelebon yang lebih besar atau setara besarnya dengan yang dilaksanakan oleh Puri Agung Ubud. Kedepan, para peneliti atau penulis dapat membandingkan makna lain biaya pada Upacara sejenis di Desa dan Puri lainnya di Bali. Selain itu, beberapa informan penting yang terlibat dalam artikel ini berasal dari lingkaran Keluarga Puri Agung Ubud itu sendiri. Peneliti selanjutnya dapat lebih menggali informan diluar keluarga pelaksana internal Puri Agung Ubud, seperti: perwakilan dari masyarakat Ubud yang juga menjadi pelaku dalam pelaksanaan Upacara Pelebon Puri Agung Ubud.

\section{DAFTAR PUSTAKA}

Anis Chariri dan Imam Ghozali. 2001. Teori Akuntansi. Semarang: Badan Penerbit Universitas Diponegoro.

Bustami, Bastian, dan Nurlela. 2009. Akuntansi Biaya. Edisi Pertama. Jakarta: Mitra Wacana Media.

Carter, William K danUsry, Milton F. 2004. Akuntansi Biaya. Diterjemahkan oleh Krista. Edisi Ketiga belas. Buku Satu. Jakarta: Salemba Empat. 
Creswell, J W 2013 Qualitative inquiry and research design: Choosing among five approaches (Third ed ) Sage publications, Singapore

Hanggana, S 2002 Kandungan Prinsip Matching dan Concervatism dalam Metode Akuntansi Piutang, persediaan, Aktiva Tetap, dan Investasi Jurnal Akuntansi dan Bisnis, Vol. 2, No. 1 , hlm 85-93

Hansen dan Mowen. 2013. Akuntansi Manajemen. Jakarta: Salemba Empat

IAI 2007 PSAK nomor 45 (Reformat) (pp $4541-45$ 22) IAI dan salemba Empat, Jakarta

Kieso, Donald, Jery J, Weygandt dan Teery D. Warfield. 2011. Intermediate Accounting. Edisi 12: Erlangga.

Kuswarno, E 2009 Fenomenologi: metode penelitian komunikasi: konsepsi, pedoman, dan contoh penelitiannya Widya Padjadjaran, Bandung

Mulawarman, A D 2008 Eksistensi Laporan Nilai Tambah Syari'ah Berbasis Rezeki Paper presented at the Simposium Nasional Akuntansi (SNA) Ke XI, Pontianak

Mulyadi. 2012. Akuntansi Biaya. Edisi ke-5. Cetakan Kesebelas. Yogyakarta: STIM YKPN..

Paton, W. A.; A. C., Littleton. 1940. An Introduction to Corporate Accounting Standards. American Accounting Association

Ratunuman, S M 2013 Analisis Pengakuan Pendapatan Dengan Persentase Penyelesaian Dalam Penyajian Laporan Keuangan PT Pilar Dasar Jurnal EMBA, Vol. 1, No. 3, hlm 576-584

Tumirin , dan Abdurahim, A. 2015. Makna Biaya Dalam Upacara Rambu Solo. Jurnal Akuntansi Multiparadigma, Vol 6, No.2, hlm 175-340. 